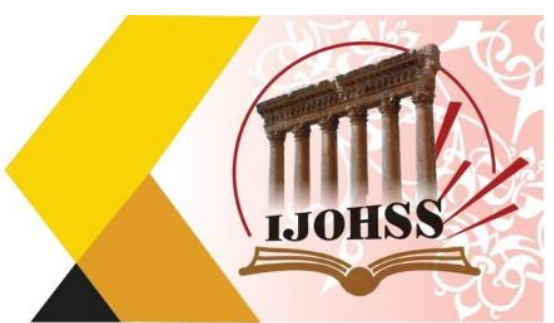

\title{
The Implication of the Interim Measures Issued by Arbitrator (A comparative analysis)
}

\author{
Abd Almohsen Alajmy \\ Kuwait \\ Email: alodaimana@gmail.com
}

\begin{abstract}
Article 173 of the Kuwaiti Arbitration Act, as a general principle, preserves the authority to issue interim measure to the court. By the language of Article 173, it can be inferred that the legislator intended to imply a number of legal prohibitions. The language of exception in Arabic legal text reflects the following norms, first: the exceptional law should be narrowly interpreted to avoid any incompatible meaning which conflicts with the general intention of the legislator. Second, it cannot be relied on in a comparative analysis to examine the legality of similarly situated issue. For instance, if the parties drafted a mediation agreement, they cannot consent to allow the mediators to issue interim relief relying on the permissibility contained in Article 173. Hence, the Arbitration Act adopted the 'duality principle' which enables courts to issue any type of preliminary relief notwithstanding parties' consent to confer this power to the arbitral tribunal. The problem is that the law does not address whether the interim relief issued by arbitral tribunal should be enforced or whether cannot be appealed, therefore the matter cannot be litigated again.

This article will trace the arbitration law approach of Kuwait, in a comparative method, in relation to the applicability of the interim measures to the resolution of the final dispute. This study will attempt to answer the question of whether the arbitrators can grant this type of relief and whether this type of orders can be enforceable according to the convention.
\end{abstract}

Keywords: arbitration, interim measures, procedural law, the authority of arbitrator. 


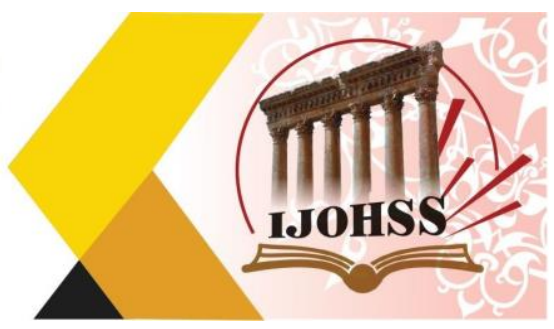

\section{Introduction}

The purpose of the interim measure is, in general, to assist the court to issue a meaningful decision by preventing damages to the claims underlying the dispute. Unlike courts, the arbitration panel lacks the coercive power to compel the parties to comply with its award. However, the arbitral award can be enforced through the national court in accordance with the New York Convention.

The issue stems from the silence of New York Convention on the power of the arbitral tribunal to issue this type of relief in addition to the enforceability of this type of orders. There are four primary issues associated with interim measures in arbitration. First is related to the authority of the arbitral tribunal to grant interim orders, second is whether this authority prevents national courts from reviewing and issuing those measures, third is whether these measures are covered by the New York Convention, therefore national courts must enforce them accordingly, last is whether the interim measure award can be appealed to the court. As a result of this ambiguity which leads to a legislative vacuum in many countries, recourse to national courts has recently become a popular technique among lawyers and advocates to halt the arbitration process.

To highlight the problem, the study will examine the comparative legal frame works to identify their approach in dealing with the arbitral power to decide interim measures and court assistance to arbitral tribunals. Also, how the judicial authority approach, regarding interim measures, has shifted over time into assistance. The article, mainly, will investigate the Kuwaiti and GCC countries approach in regulating the provisional measures in terms of its refusal to recognize the exclusivity of the arbitration.

The study will employ a comparative method to assess the Kuwaiti Arbitration Law within the GCC countries, UK and U.S. as the last two jurisdictions are optimal examples that have dealt with the loophole of New York Convention in the context of the competent entity in granting interim measures when the dispute is subject to arbitration and filled that gap by either a legislative amendment or through case law.

\section{Legal Framework of The Interim Measures}

The arbitration legal regime has invented instruments to protect parties' rights from potential damage pending an award, and ensure expeditious settlement through arbitral proceeding. The most significant tools are interim measures, which provide parties with temporary protection until the final award is issued. ${ }^{1}$ For instance, in

1 See William Wan, International Arbitration: the Need for Uniform Interim Measures of Relief, (2003), 28 BROOK. J. INT'L L. 1059, 1061 (“Interim Measures are an absolute necessity to protect what is a stake in the arbitration. Regardless of whether evidence, real property, personal property, or financial assets needs to be preserved, there must be an effective procedure for maintaining the status quo. Without the protection of such provisional remedies the outcome of the arbitration could become meaningless to the winning party."). 


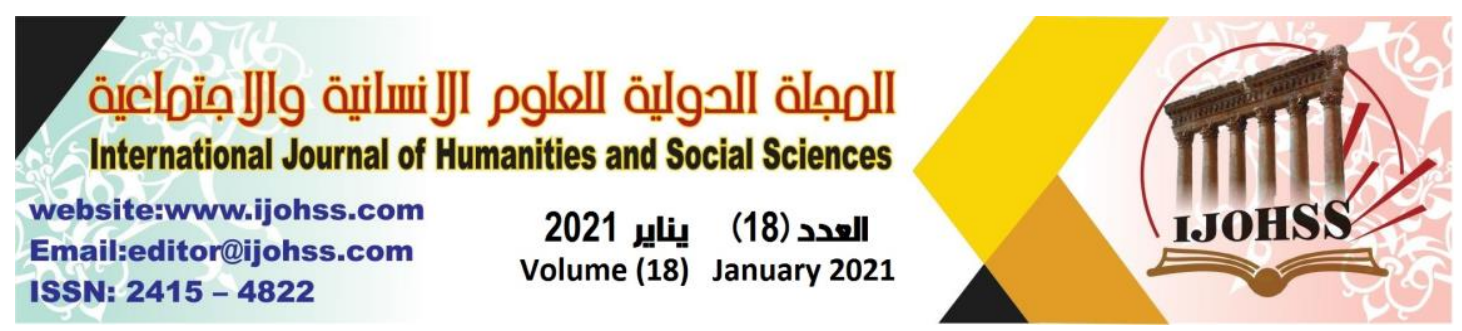

Yahoo! Inc. v. Microsoft Corp. the court confirmed an award granted by an emergency arbitrator appointed under the AAA rules to issue emergency relief "until the matter can be fully and fairly decided by a three arbitrators' panel of industry experts following discovery". ${ }^{2}$ The Yahoo! case proves how quickly provisional measures can be obtained in arbitration. The emergency arbitrator held two days of evidentiary hearings starting 11 days after Microsoft initiated arbitration and issued a decision six days after the conclusion of those hearings.

Currently, the vast majority of legislative regimes regulating arbitration acknowledge the right of the arbitral tribunal to grant interim measures during the arbitral process. ${ }^{3}$ These measures can be referred to in different terms. Article 9 of UNCITRAL Model Law Rules of Arbitration describes it as interim measures of protection. Kuwaiti Civil procedures Law uses the term of summary matters, the Belgian Act Article 1696 describes it as provisional and protective measures, while the German Arbitration Law 1998 Article 1041 refers to it as interim measures of protection. The purpose of the interim measure is to assist the court in issuing a meaningful decision by preventing damages such as irreparable harm to the claims underlying the dispute. In general, interim measures fall within three categories; first, they are used to maintain the status quo to ensure the effectiveness of the award, which concerns, for example, conservation of goods, machinery or work' use and maintenance. The second category involves enforcing the parties to satisfy their contractual obligation including preservation of property information and trade secrets. The last group relates to the protection of evidence. ${ }^{4}$ The standard of issuing these measures is predicated on urgency. In other words, the interim measure is a remedy that safeguards the parties' right before the final decision is finalized, and they are temporary in nature.

An arbitral tribunal, unlike a court, lacks coercive power to enforce its decision against the parties or to compel a third party to comply with the arbitral orders, ${ }^{5}$ which necessitates court assistance to enforce the award. ${ }^{6}$ Parties may tend to recourse to court instead of requesting the interim measures from the arbitral tribunal to save their times. ${ }^{7}$

\footnotetext{
${ }^{2}$ Yahoo! Inc. v. Microsoft Corp (983 F. Supp. 2d 310 (S.D.N.Y. 2013).

3 See Kuwait procedural Law Articl 173; Qatar Arbitration Law Article 17; American Federal Arbitration Act of 1925 and American Federal Arbitration Act of 1970; Belgian Judicial Code of 1985 Articles 1679 (2) and 1696 (1), Dutch Civil Procedural Law issued July 1st, 1986 Article 1022, British Columbia International Commercial Arbitration in Canada of 1988 Article 17(1), Swiss Private International Law of 1987 Article 183.

4. Ghazwi, M. F., Jarrah, M., \& Mahasneh, Critical Analysis of Granting Interim Measures in Arbitration in the Context of Jordan Arbitration Law No. 16. 2018, 10 BeIJING LAw REviEw, 1100, 1103

${ }^{5}$ Ali Yesilirmak, Provisional Measures in International Commercial Arbitration, 2003, University of London, at 8.

${ }^{6}$ Lira Goswami, Interim Relief: The Role of the Courts in International Arbitration and National Courts: The Never Ending Story“ ICCA Congress Series No. 10, KLUwER L. INT’L, 111.

7 Alan Redfern, J.Martin H. Hunter, et., Law and Practice of International Commercial Arbitration, Thomson Sweet\& Maxwell, 2004, 7-18.
} 


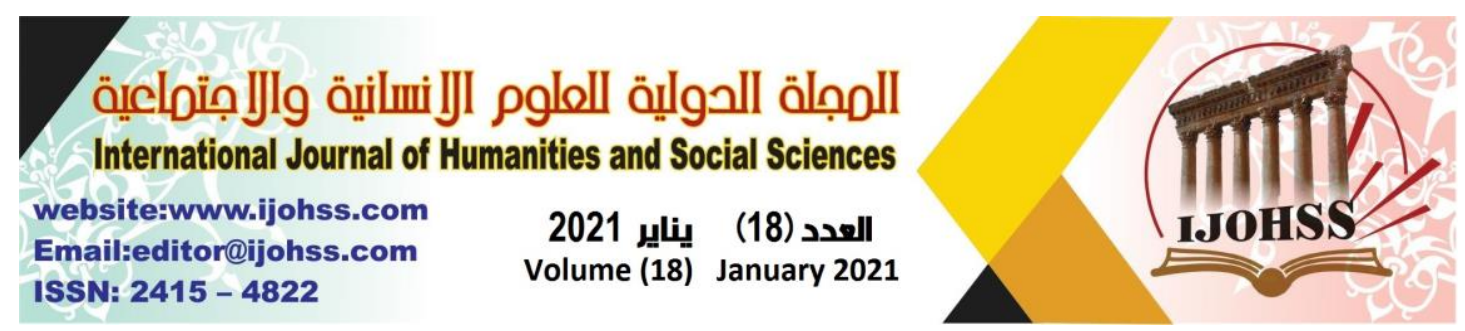

Since the interim measures play a significant role in the arbitration process in terms of protecting the right at stake, the critical question here who is competent to grant interim measures? Is it the arbitral tribunal exclusively? Or the court? Or both?

The interim measure award is preliminary order and does not settle the case. The issuance of this type of relief is conditional upon some requirements such as urgency. New York Convention does not address the competency of the arbitrators to issue interim measures award

\section{The Interim Measures in Kuwaiti Arbitration Law}

Kuwaiti Arbitration Law Article 173, for example, stipulates that the interim measures, in case there is an arbitration clause, are subject exclusively to the national court review unless parties have agreed to endow the power of issuance of these measures to the arbitral tribunal.

Article 186 of the Arbitration Act states that: "Any concerned party may request nullification of the final arbitrator's award in the event of the following cases, even when otherwise is agreed upon prior to its rendering." The test applied to determine the finality of the judicial decision, according to the procedural law, is defined in Article 128 as a final decision which settles the entire dispute.

That means the Kuwaiti arbitration Act distinguishes between the preliminary and final award in terms of vacation and confirmability. Practically, the ambiguity of this language raises many questions; First, and foremost, is that the text classifies the interim measures issued by the tribunal as not final decision which means it is not covered by the New York Convention, thus the court is not obliged to enforce it, Second, based on the text, notwithstanding the parties' agreement to grant the arbitration the power to issue interim measures type of relief, Kuwaiti courts are still able to do so which might lead to an overlap of jurisdiction between the national court and the arbitral tribunal. This overlap will cause a contradictory decisions that cannot secure an effectiveness of the arbitration in Kuwait.

Scholarly opinions, around the world, are split on this problem. For example, in defining the finality of the arbitral award, the United State Court of Appeal for Seventh Circuit stated: "we take 'mutual' and 'final' to mean that arbitration must have resolved the entire dispute." 8

The approach of Kuwaiti Arbitration Act is anomalous in the realm of interim measures. One of the issues the law does not address is whether the interim relief issued by arbitral tribunal has can be enforceable therefore it cannot be litigated again. Assume a case brought before the court, two companies have entered into a merger contract and inserted an arbitration clause to their agreement in the hope that they resolve any problem resulting out of their agreement through arbitration. These

\footnotetext{
${ }^{8}$ IDS Life Insurance Co. v. Royal Alliance Associates Inc., 266 F.3d 645, 650 ( $7^{\text {th }}$ Cir. 2001).
} 


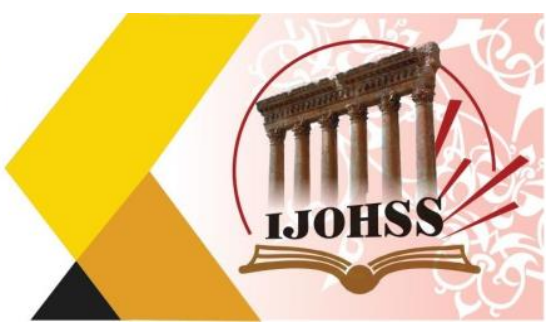

parties, further, consented to authorize the arbitral tribunal to issue urgent measures upon the request of any party. During the execution of the transaction, company (A) discovered that company (B) presented misleading information relating to the market value of its assets (two towers). The acquirer (A) submitted a preliminary request to the arbitral tribunal to suspend the transaction and designate a committee to determine the actual price of those assets. Company (A) also resorted to the Kuwaiti court asking for the same decision, even though it had granted the arbitral tribunal to issue interim measures. Since the Kuwaiti Arbitration Law is silent on the question whether the court is prohibited from issuing and reviewing the interim measures orders issued by the arbitration panel if both parties consented to empower the arbitral tribunal with this authority, the court still can exercise its authority in this regard and grant a temporary order. Then if by the time the court issued its ruling, and if the arbitral tribunal had already made a final judgement, what happens if the arbitral tribunal ruled in favor of the plaintiff, whereas the court rejected the claim. In addressing whether the court may rely on its jurisdiction to issue these types of measures even when the parties have already agreed to give this power to arbitral tribunal, the court stated according to article 173 of the Arbitration Act.

According to Kuwait Civil Procedure Law Article 173, interim measures are subject to the domestic court. However, the article contains an exception allowing the parties to grant the arbitral tribunal the ability to issue those measures if both parties specified that, in an explicit language, in the agreement. Therefore, Kuwaiti Arbitration Act recognizes the jurisdiction of the arbitrators over the provisional measures.

Article 173 of the Arbitration Act, as a general principle, preserves court's authority to issue interim measure to the court. By the language of Article 173, it can be inferred that the legislator intended to imply a number of legal prohibitions. The language of exception in Arabic legal text reflects the following norms, first: the exceptional law should be narrowly interpreted to avoid any incompatible meaning which conflicts with the general intention of the legislator. Second, it cannot be relied on in a comparative analysis to examine the legality of similarly situated issue. For instance, if the parties drafted a mediation agreement, they cannot consent to allow the mediators to issue interim relief relying on the permissibility contained in Article 173. Hence, the Arbitration Act adopted the 'duality principle' which enables courts to issue any type of preliminary relief notwithstanding parties' consent to confer this power to the arbitral tribunal.

\section{Finality Issue}

The finality of the arbitral award appears as the prominent reason for not confirming the arbitral decision. Courts have alleged that new York Convention explicitly regulates the final ruling to be confirmed and enforced not preliminary decision of the arbitration. 


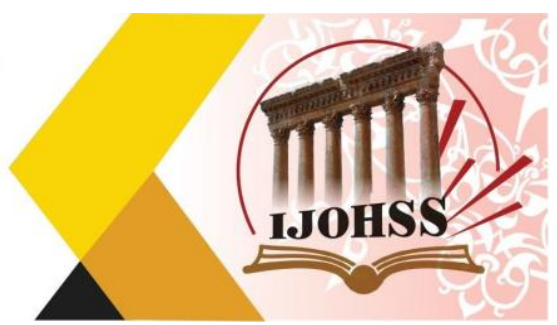

A. The issue of finality in Kuwait

In international context, in the US some courts refused to recognize interim measures issued by arbitral panel as they are not confirmable under the Federal Arbitration Act (FAA). This problem has materialized in many cases as a justification to refuse the recognition the arbitral award. In defining the word "final," the seventh circuit court of appeal stated: "we take 'mutual' and 'final' to mean that arbitration must have resolved the entire dispute." 9

Similarly, in Kuwait, Article 173 distinguishes between the arbitral award of interim measures and the award that settles the substantive issue as there is a requirement for an additional consent for the interim measures award to be binding. Otherwise, it would not have given the court the ability to decide provisional measures claim while it is subject to the arbitration. The question is how would the court handle the case if the party, who has obtained interim award, resorts to court to have it confirmed pursuant to Article 185 despite the rejection of the same claim by the court.? The enforcement of the arbitral award is regulated by Article 185 which provides that the arbitral award can only be enforced if it has been confirmed by the trial court. Notably, the Arbitration Act, which is part of the Civil Procedural Law; does distinguish between interim relief award and the final award in terms of finality. For instance, the preliminary injunction issued by the arbitral panel can be appealed to the court, the reason is because the Article 173 does not preclude the jurisdiction of the court over interim measure claims. Also, Article 186 states: "any party can submit a claim to vacate the final award issued by arbitral tribunal." Does that mean the procedural method applied to the award that settled the substantive issue does not apply to interim measures award.?

In my opinion, this distinction would vest the court with wide discretionary authority as the interim measures issued by arbitral tribunal is treated as a final award then the Arbitration Act would be the applicable law, and the court can only vacate the award without delving into the merits. In the current practice, some courts do not recognize interim measures award as a final award, which triggers the Civil Procedures rules as applicable law not Arbitration Act. Therefore, that gives the court full jurisdiction, and this is the problem. Likewise, a number of US courts characterized interim measures as not final arbitral award. ${ }^{10}$

\section{B. The Finality Issue of Interim Measures Award in the US}

The finality of interim measures award appears to be problematic in the US legal system as well. The prevailing party would seek to confirm the award pursuant to Article 9 of FAA, while the adverse party would challenge the confirmability of the

\footnotetext{
${ }^{9}$ IDS Life Insurance Co. v. Royal Alliance Associates Inc., 266 F.3d 645, 650 ( ${ }^{\text {th }}$ Cir. 2001).

${ }^{10}$ Michaels v. Mariform Shipping, S.A., 624 F.2d 411, 413-15 (2d Cir. 1980) (finding that it "does not purport to be final but is merely a first step in deciding all claims submitted to arbitration".)
} 


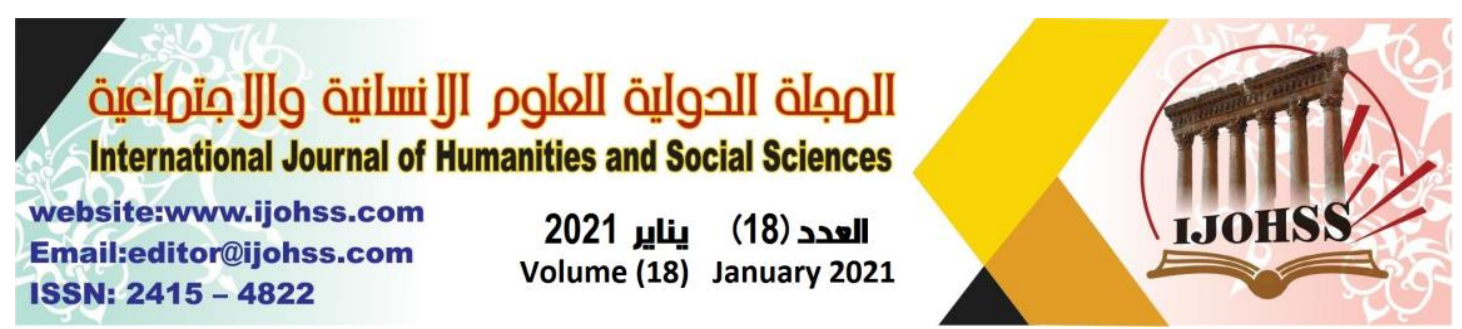

award on the ground that the award is not final. The question is how can we determine the finality of the award.?

The seventh US circuit court of appeal defined the final as: "The arbitrators must have resolved the entire dispute (to the extend arbitrable)." 11 The characterization of the award would trigger different applicable law. The court in YASUDA v. Continental stated: "As mentioned, Yasuda brings its claim under section 10 as a petition to vacate, not section 9. While the two statutes apply to two different procedural postures (the winner of an award may petition to confirm under section 9, and the loser may petition to vacate under section 10), they are the same as a practical matter. The district court must confirm the award unless that award must be vacated under section 10 (or modified or corrected under Section 11."12

Courts have established many theories where the award would be deemed final. In YASUDA $v$. Continental, the court held that panel's order requiring the defendant to post interim letter of credit necessary to protect a possible final award was confirmable award under FAA. ${ }^{13}$ The award to preserve assets in order to make the final award meaningful would, also, be deemed a confirmable final award.

In expanding the methods to prove the finality of the award, the court accepted The agreement in Ace/Clear Defense stated that: "The decision of the arbitration shall be final and binding upon each party and may be enforced in any court of competent jurisdiction." Notably, this provision did not explicitly limit "decision" to just a final award. The circuit court, therefore, agreed that the contractual language "is sufficient to satisfy Section 9's requirement that the parties' have agreed that a judgment of the court shall be entered upon the award." 14

Evidently, there is no normative definition of final award. Even though defining the final award by considering some determinant factors, the factors mentioned above by the courts are unreliable as they overlap and complement each other, therefore, cannot form a definite meaning of the final award though.

\section{The Court position of Granting Interim Measures While the Dispute is subject to Arbitration}

Some courts have ruled that courts lack power to issue interim relief if the underlying dispute is subject to an arbitration agreement governed by the New York Convention. ${ }^{15}$ Other courts, however, have granted interim relief pending arbitration

\footnotetext{
${ }^{11}$ IDS Life Insurance Co. V. Royal Alliance Associates Inc., 266 F.3d 645, 650 ( $7^{\text {th }}$ Cir. 2001).

12 Yasuda Fire \& Marine Ins. Co. of Europe u. Continental Casualty Co., 37 F3d 345, 347-48 (7th Cir. 1994). 13 Id.

${ }^{14}$ See Home In- surance Co V. RHAIPennsylvania Nursing Homes Inc., 127 E.Supp. $2 d$ 482, 485 (S.D. N.Y. $2001)$.

15 see, McCreary Tire \& Rubber Co. v. CEAT S.p.A., 501 F.2d 1032, 1037-38 (3d Cir. 1974) ; I.T.A.D. Assocs., Inc. v. Podar Bros., 636 F.2d 75 (4th Cir. 1981)); also In Merrill Lynch, Pierce, Fenner \& Smith v. Hovey, the Eighth Circuit stated that "a preliminary injunction was inappropriate in an arbitrable controversy where the parties did not specifically provide for it in their agreement' (726 F.2d 1286, 1292 (8th Cir. 1984);
} 


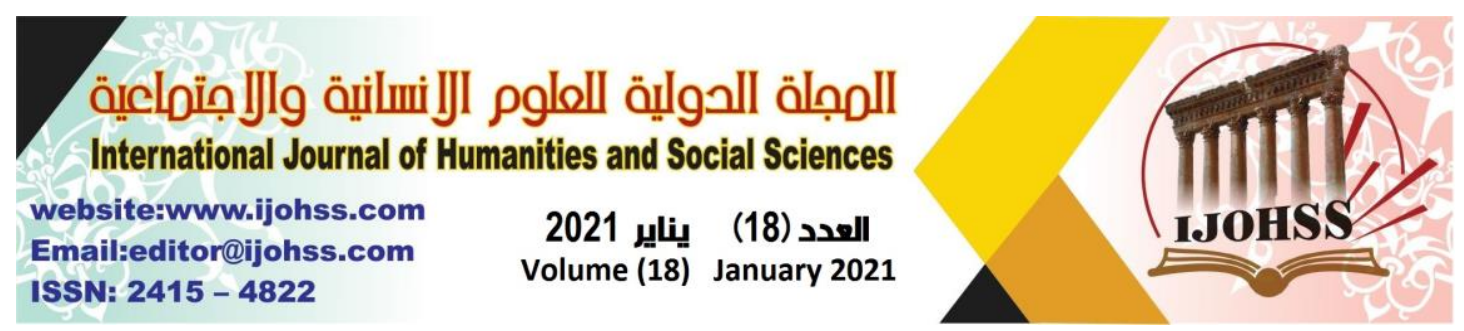

stating that courts may issue these types of measures under the FAA. ${ }^{16}$ The validity of the provisional measures granted by the court also vary. In general, Court-issued interim relief is effective until the the arbitral tribunal has the opportunity to consider the application for emergency or injunctive relief. ${ }^{17}$ Other courts extend the legal effect of the interim measures until the arbitrators render an award. ${ }^{18}$

The difficulty arises when a party recourses to both arbitral tribunal and the court to obtain interim relief in the hope of having more favorable ruling. Courts would accept the claim as there is nothing in the Arbitration Act preventing the court from deciding a claim that has been submitted to the arbitral tribunal. Courts and arbitral tribunals are not bound by the principles of lis pendens and res Judicat.

In this situation, the only possibility is the court would deny enforcement because the award has res Judicata. If the same claim was decided by the arbitral panel, the court still can entertain application since the court and arbitral tribunal are not bound by the principles of lis pendens and res Judicata.

If there is conflicting decisions, in the context of interim measure, between the court and arbitral tribunal. One might suggest that parties may invoke Article 138 that addresses the matter of contradictory rulings, this article confers to the court of appeal the authority to examine the decision of the trial court if it conflicts with another decision issued by other court if it is uncontestable. Since enforcing the arbitral award falls within the scope of the trial court $^{19}$, then the award can be appealed multiple times which renders the arbitration useless.

There is no legitimate legal or practical reason for the court to entertain the parties' application for interim measures. Particularly, when the arbitral tribunal has adjudicated the claim, one of the reasons supporting this view is the res judicata doctrine, which should be adopted by the Kuwaiti law. It bars the party from litigating the same issue twice. Therefore, this study, will endeavor to set the boundaries between the courts and the arbitral tribunal competency when it comes to the jurisdiction over a dispute that is subject to the arbitration ${ }^{20}$, as the court always relies on the lack of clarity of rules of interim measures.

\footnotetext{
16 See Aggarao v. MOL Ship Mgmt. Co., 675 F.3d 355, 376 (4th Cir. 2012), Karaha Bodas Co.v Perusahaan Pertambangan Minyak Dan Gas Bumi Negara, 335 F.3d 357, 365 (5th Cir. 2003); Merrill Lynch, Pierce, Fenner \& Smith, Inc. v. Salvano, 999 F.2d 211, 214-15 (7th Cir. 1993); Blumenthal v. Merrill Lynch, Pierce, Fenner \& Smith, Inc., 910 F.2d 1049, 1051-54 (2d Cir.1990; Borden, Inc. v. Meiji Milk Prods. Co., 919 F.2d 822, 826 (2d Cir. 1990); Rhone Mediterranee Compagnia Francese Di Assicurazioni E Riassicurazoni v. Lauro, 712 F.2d 50, 54-55 (3d Cir. 1983); and Sojitz Corp. v. Prithvi Info. Solutions Ltd., 921 N.Y.S.2d 14, 17 (1st Dep't 2011).

17 See Fairfield Cnty. Med. Ass'n, 557 F. App'x, 56; Med. Co. v. Johnson \& Johnson Int'1, 619 F.3d 67, 70 (1st Cir. 2010); and Merrill Lynch, Pierce, Fenner \& Smith, Inc. v. Salvano, 999 F.2d, 215.

18 See Bailey Shipping Ltd. v. Am. Bureau of Shipping, 2013 WL 5312540, 18 (S.D.N.Y. Sept. 23, 2013); Amegy Bank Nat'l Ass'n v. Monarch Flight II, LLC, 870 F. Supp. 2d 441, 452-53 (S.D. Tex. 2012).

${ }^{19}$ Article 185 Civil Procedural act.

${ }^{20}$ The study will not attempt to set a universal standard of the authority of granting interim measures between national court and the arbitrator, rather, it will focus on the Kuwait legal position in allocating
} 


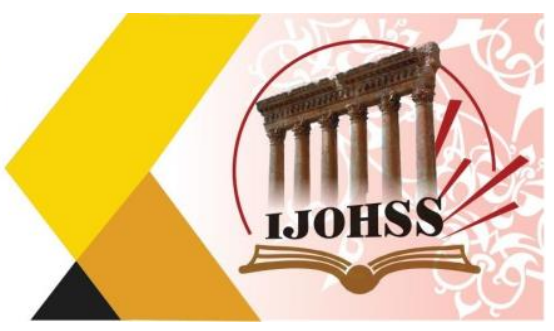

Domestic courts play fundamental roles at different phases of arbitration proceedings. Despite the developments in international arbitration in the current time, such involvements can be necessary on some occasions but not in all. What we can see regarding the court involvement in the process of the arbitration goes back to the early stages of international arbitration before the Second World War when it was not as prevalent among the world ${ }^{21}$. Therefore, when states, for example US, decided to boost the utilization of this dispute settlement mechanisms, they rely on the significant role of domestic laws to clarify the ambiguity of existing rules in the Federal Arbitration Act by allowing the court to play a different roles in securing the efficiency of the arbitration. Example of that when the courts, as mentioned above, attempted to interpret Article 9 of FAA as refers to arbitral award not final award.

Therefore, in the current time, national courts can get involved in an arbitration process before the establishment of the tribunal until the recognition and enforcement of the arbitral award. Accordingly, the potential basis for court involvement in the arbitration may have two underlying reasons: the application of the national laws and party autonomy. Hence, national courts may get involved in arbitration first and foremost because there are permissive national laws and because parties encourage them to do so.

However, a study of international arbitration, specially after the execution of the New York Convention, shows that the discretion of the national courts may sometimes function as a double-edged sword and undermine the independence of arbitration. Example of that would be, in exercising its discretionary authority, the court may issue interim relief to prevent damages to claims underlying the dispute, to the contrary, the court may issue interim measure that would destroy the purpose of the arbitration agreement. For instance, when a party resorts to the court to seek injunction relief, if the court granted that relief, the arbitration process would pause until the litigation before the court by both parties is settled. Thus, there is no point for reconciling or alleviating court involvement in arbitration process, without first, and foremost, draw the distinction between these two judicial regimes.

Despite the fact that a large number of solutions, including harmonization of arbitration rules and the arbitration process, have been proposed to resolve this problem, court involvement at its current level has become a threat to the independence and functionality of both national and international arbitration, The reason for that is because recently recourse to national courts has become a popular technique among lawyers and advocates to halt the arbitration process. Consider this situation, when the arbitral proceeding is initiated by a party, the defendant may recourse to the court asking for preliminary injunction, since there is no prohibition,

this power between these two different judicial entities and point out the lacunas in the Kuwaiti Civil Procedural rules.

${ }^{21}$ Frank D. Emerson, History of Arbitration Practice and Law, 19 Clev. St. L. Rev. 155 (1970), 160. 


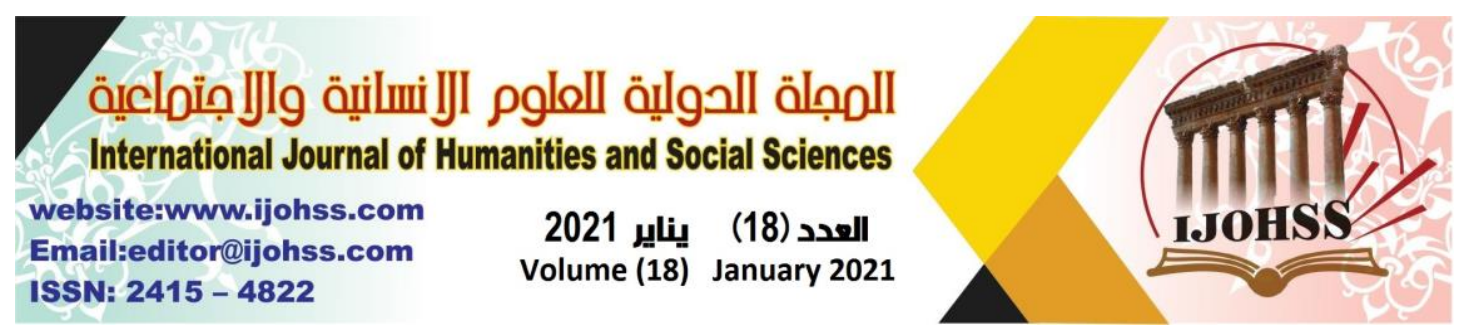

the case will take time in court to be decided which will enforce the panel to pause the arbitral proceeding. Consequently, that will cause the plaintiff damages.

The countries of this study have different approaches with respect to both court and tribunal's authorities to intervene in the arbitration process, particularly to issue interim relief or emergency orders and the implications on the continuity of the arbitral proceeding:

\section{A. U.S Approach in The Context of Interim Measures}

In the United States, a number of courts have declined to enforce interim measures award where they determined that the measures were not "final" awards. ${ }^{22}$

Despite the apparent language of the Model Law, the FAA does not include any provision with respect to the arbitrators' ability to grant interim measures. Such a lacuna may be filled by recognition of the ability of arbitrator to grant such measures by the national courts. Therefore, in comparison with early US judicial decisions which is on the basis of narrow interpretation of the parties' arbitration agreement frequently emphasized an inability of arbitrators to issue provisional relief, ${ }^{23}$ in recent US lower court decisions have consistently ruled that arbitrators may grant provisional measures "on a condition that the parties have not agreed to the contrary". ${ }^{24}$ Indeed, it seems that a refusal to recognize the authority of the arbitrators in issuing interim measures would be inconsistent with the FAA's ratio legis that agreements to arbitrate are enforceable. ${ }^{25}$

Even at the domestic courts level, US state arbitration statutes have gradually developed towards incorporation of provisions pertaining to arbitrators' authority to grant provisional measures. ${ }^{26}$ More importantly, US courts, in general, are adopting the view that in the absence of a contrary indication, the arbitrators' authority to grant provisional measures can be implied from the parties' agreement to arbitrate. ${ }^{27}$ As one US lower court decision stated:

In general ..., in the absence of an agreement or statute to the contrary, an arbitrator has inherent authority to order a party to provide security while the arbitration is continuing. It is reasonable to assume that parties, in agreeing to arbitration, implicitly intended that the arbitration not be fruitless and that interim orders to preserve the status quo or to make meaningful relief possible would be

\footnotetext{
${ }^{22}$ Mitsubishi Heavy Indus., Ltd. v. Stone \& Webster, Inc., No. 08 Civ. 00509 (JGK), 2009 U.S. Dist. LEXIS 91199, 13-20.

${ }^{23}$ See Swift Indus, Inc v Botany Indus, Inc 466 F2d 1125, 1134 (3d Cir 1972); Carolina Power Light v Uranex, 451 F Supp 1044 (ND Cal 1977).

${ }^{24}$ See, Banco de Seguros del Estado v Mut Marine Office, Inc, 344 F3d 255 (2d Cir 2003) and Pacific Reins Mgt Corp v Ohio Reins Corp 935 F2d 1019, 1022-1023 (9th Cir 1991).

25 See Born G, International Arbitration and Forum Selection Agreements: Drafting and Enforcing, 2nd edn, Kluwer 2006, 141-142, 206-207, 571-572.

${ }^{26}$ US Revised Uniform Arbitration Act, section 8(b) (2000); See California Code of Civil Procedure, paras 1297.91 to 92, 1297.171; Texas Civil Practice \& Remedies Code, para 172.083(1).

${ }^{27}$ See, for example, Island Creek Coal Sales Co v City of Gainesville 729 F2d 1046 (6th Cir 1984) and Sperry Int'l Trade, Inc v Gov't of Israel 689 F2d 301 (2d Cir 1982).
} 


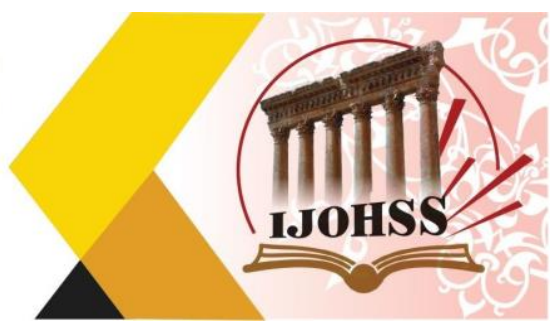

proper. In such a circumstance, the arbitrator's authority to act would reasonably be implied from the agreement to arbitrate itself. $^{28}$

It can be noticed that the US approach, in court precedents, does not impose significant limitations, rather than those incorporated in the parties' agreement, on the scope of the arbitrators' authority to grant provisional measures. ${ }^{29}$ As a result, most commentators in the US conclude that arbitral tribunals have the authority to order interim relief (unless otherwise agreed). ${ }^{30}$

\section{B. UK Approach (Subsidiarity)}

UK Arbitration Act 1996 presents an original approach to addressing the issue of interim measures in aid of arbitration. Jan K. Schaefer calls this approach "the court subsidiarity model." This act addresses the matter of interim measures and permits, in the absence of the contrary agreement, an arbitral tribunal to grant orders concerning the inspection, sampling, detention or preservation of 'property which is the subject matter of the dispute', ${ }^{31}$ and concerning the preservation evidence. ${ }^{32}$ More importantly, the Arbitration Act provides that 'the parties are free to agree that the tribunal shall have power to order on a provisional basis any relief which it would have power to grant in a final award. ${ }^{33}$

It seems that the UK Arbitration Act takes the least desirable approach in contrast to both the Model Law and FAA - including the precedents of the US courts - assume broader powers for arbitrators, according to the parties' intention, to grant interim measures. In any event, in my view the expansion of the arbitral tribunal power in granting interim measures accords better with the expectations of market practitioners and will more likely secure fairness and efficient than the limited English statutory provision. $^{34}$

\footnotetext{
${ }^{28}$ Charles Constr Co v Derderian 586 NE 2d 992 (Mass 1992); see also Gilmer v Interstate/Johnson Lane Corp 500 US 20 (US S Ct 1991).

${ }_{30}^{29}$ See Born, supra (n 22) 2026-2028.

30 See MF Hoellering, 'The Practices and Experience of the American Arbitration Association' in ICC, Conservatory and Provisional Measures in International Arbitration (Kluwer 1993); Christopher Higgins, Interim Measures in Transnational Maritime Arbitration, Tulane L. Review 1519, 1535-36.

${ }^{31}$ UK Arbitration Act 1996, section 38(4). See Merkin. R, Arbitration Law, 2004, 14.57 to 14.58.

${ }^{32}$ Id section 38 (6). The Arbitration Act also allows the arbitral tribunals seated in England the authority to order security for costs, see section 38 (3); Born (n 22) 2004-2006.

${ }^{33}$ UK Arbitration Act 1996, sections 38 (1), 39 (1). See also section 48.

${ }^{34}$ See Born (n 22), 1953-1954.
} 


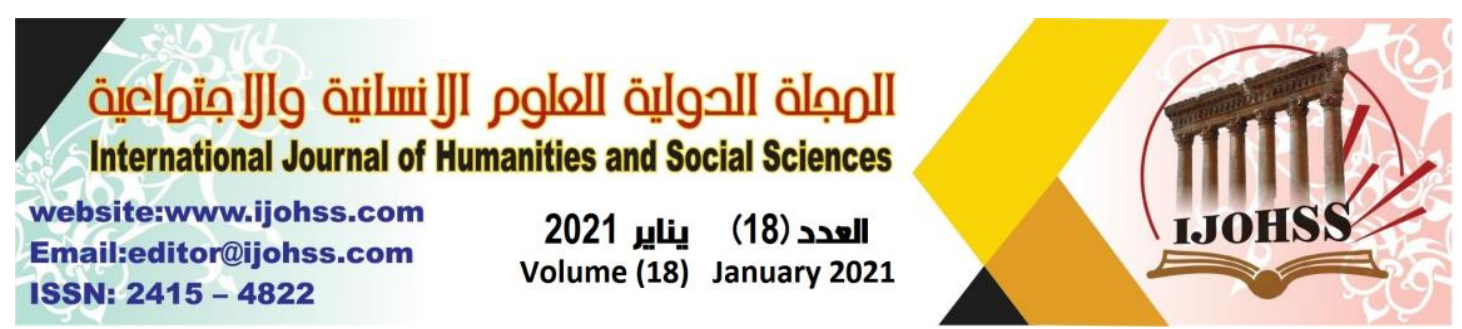

\section{The Legal Framework of Interim Measures in Qatari Law}

Qatar's rules are consistent with its approach with respect to the limitation and allocation of the authority between the national court and the arbitration. Like FAA, the rules allow the tribunal to grant interim measures, unless agreed otherwise ${ }^{35}$ in the prescribed situations such as preservation of evidence and measures to protect the process of the arbitration. In clarifying the right of the aggrieved party, the rules explicitly state that the appeal of the tribunal's decision is restricted only to vacate the arbitral award when one of the situations set forth in the text exists, none of them the interim measures. The conclusion of the text, apparently, reiterates the authority of the tribunal to grant preliminary measures set forth in the text. However, one issue may arise when the parties did not agree to convey the arbitral tribunal the power to issue interim relief. Can the aggrieved party appeal the court decision to the arbitration if it agrees after the decision was issued and there is no objection by the counter-party?

\section{Institutional Rules Regarding Interim Measures}

The hurdles of arbitrators' power in granting interim measures are also addressed in many institutional rules. The general tendency taken is to incorporate specific provision concerning arbitrators' authority to grant interim measures, usually in relatively broad terms. For example:

\section{A. UNCITRAL Approach}

The UNCITRAL Rules, as represent many contemporary institutional regimes, recognizes the tribunal's power to grant 'interim measures' which is considered "necessary in respect of the subject matter of the dispute, including measures for the conservation of the goods forming the subject matter of the dispute". 36

The only limitations to the tribunal authority are those under Article 17 of the UNCITRAL Model Law. However, these two limitations should not be interpreted to hold a tribunal from ordering the inspection, detention or preservation of disputed goods or property, rather, such terms in plain intend to permit any provisional measures that the tribunal considers 'necessary' provided that such measures have a legitimate connection with the contract, legal or contractual rights of all parties. ${ }^{37}$

\footnotetext{
${ }^{35}$ Art 17 Act 2 Issued 2017.

36 UNCITRAL Rules, art 26 (1).

37 Article 26 (1) of the UNCITRAL Rules stipulates merely that an order for the conservation of goods which are in dispute is one example of permissible interim relief, not suggesting that this is the only form of permissible relief.
} 
العدد (18) يناير 2021

Volume (18) January 2021

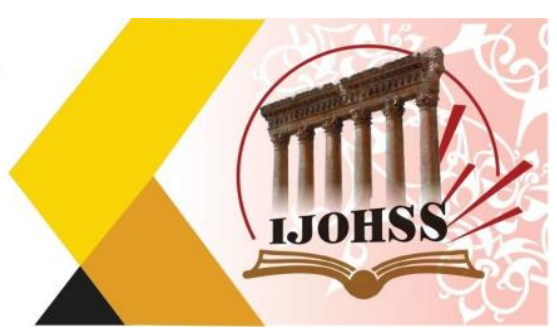

\section{B. ICC \& LCIA}

ICC Rules, specifically Article 23, take even more expansive view by recognizing the arbitral tribunal power to order any "interim or conservatory measure it deems appropriate," in the absence of a contrary agreement by the parties. ${ }^{38}$ likewise, Article 25(1) of the LCIA Rules states that the authority of an LCIA tribunal, again subject to contrary agreement by the parties, to grant various types of provisional measures including security for claims, preservation or sale of disputed property, and any other relief which can be made in a final award. ${ }^{39}$ Even more interestingly, the LCIA Rules recognize certain authorities for the arbitrators to order security for costs which can exclusively be found here. ${ }^{40}$

Number of scholars emphasize that the law does not divest the court's jurisdiction by Article 173 of the Arbitration Law, and the loopholes in the can be cognizable without amending the law. ${ }^{41}$ I respectfully disagree, the law should not be read in vacuum, the procedural regime in Kuwait legal system proves the opposite.

\section{Conclusion}

The Right of the court to review the interim measure issued by the arbitral tribunal can seriously frustrate the pros of arbitration process and its neutrality. Arbitration has possessed a significant role in the sense that it has grown its roots and has become an recognized mechanism for settling disputes in non-business sectors, such as employment and construction cases, in which the drafters of the Kuwaiti Law likely never anticipated arbitration would be a settlement mechanism in those cases. ${ }^{42}$

National courts play multiple roles at different phases of international arbitration. Given the current effectiveness of the international arbitration, such involvements may be necessary in some situations but not in all. In the current time, national courts may intervene in an arbitration process even prior to the constitution of the tribunal up to the recognition and enforcement of the foreign award. However, a study of international arbitration, in particular after the implementation of the New York Convention, shows that the discretionary authority of the court operates as a doubleedged sword and undermine the neutrality and functionality of the arbitration.

\footnotetext{
${ }^{38}$ ICC Rules, art 23.

${ }^{39}$ LCIA Rules, art 25 (1).

${ }^{40} I d$ art 25 (2).

${ }^{41}$ Azmi Abdulfatah, Kuwaiti Arbitration law, 2007, 517.

${ }^{42}$ See Sarah Rudolph Cole, Incentives and Arbitration: The Case Against Enforcement of Executory Arbitration Agreements Between Employers and Employees, 64 UMKC L. REV. (1996) 449, 462-67.
} 


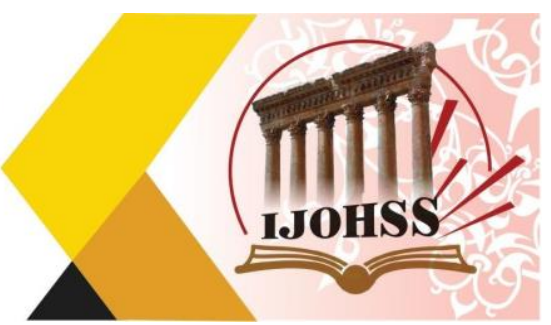

Therefore, there is a significant need to reconcile as well as minimize court involvement in arbitration process.

This study recommends the Arbitration Act be reformed in a way that draws the line between the scope of the court authority and the arbitral tribunal in the context of interim measures.

\section{Reference}

\section{Books \& Articles:}

1. William Wan, International Arbitration: the Need for Uniform Interim Measures of Relief, (2003), 28 Brook. J. Int'l L.

2. Ghazwi, M. F., Jarrah, M., \& Mahasneh, Critical Analysis of Granting Interim Measures in Arbitration in the Context of Jordan Arbitration Law No. 16. 2018, 10 Beijing Law Review

3. Ali Yesilirmak, Provisional Measures in International Commercial Arbitration, 2003

4. Lira Goswami, Interim Relief: The Role of the Courts in International Arbitration and National Courts: The Never Ending Story' ICCA Congress Series No. 10, Kluwer L. int'l.

5. Frank D. Emerson, History of Arbitration Practice and Law, 19 Clev. St. L. Rev. 155 (1970)

6. MF Hoellering, 'The Practices and Experience of the American Arbitration Association' in ICC, Conservatory and Provisional Measures in International Arbitration (Kluwer 1993)

7. Christopher Higgins, Interim Measures in Transnational Maritime Arbitration, Tulane L. Review

8. Sarah Rudolph Cole, Incentives and Arbitration: The Case Against Enforcement of Executory Arbitration Agreements Between Employers and Employees, 64 UMKC L. REV. (1996)

9. Azmi Abdulfatah, Kuwaiti Arbitration law, 2012

10. Born G, International Arbitration and Forum Selection Agreements: Drafting and Enforcing, 2nd edn, Kluwer 2006

11. Born G, International Arbitration and Forum Selection Agreements: Drafting and Enforcing, 2nd edn, Kluwer 2006

\section{Case Laws:}

1. Yahoo! Inc. v. Microsoft Corp (983 F. Supp. 2d 310 (S.D.N.Y. 2013).

2. IDS Life Insurance Co. v. Royal Alliance Associates Inc., 266 F.3d 645, 650 (7th Cir. 2001).

3. Home In- surance Co V. RHAIPennsylvania Nursing Homes Inc., 127 E.Supp. 2d 482, 485 (S.D. N.Y. 2001).

4. McCreary Tire \& Rubber Co. v. CEAT S.p.A., 501 F.2d 1032, 1037-38 (3d Cir. 1974) 


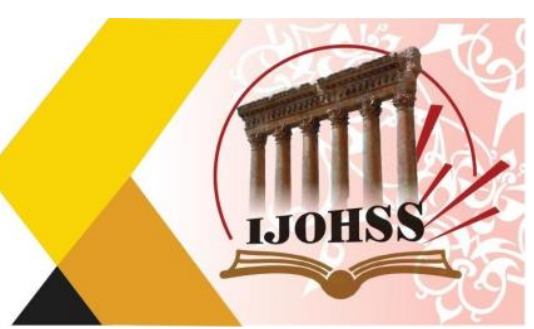

5. I.T.A.D. Assocs., Inc. v. Podar Bros., 636 F.2d 75 (4th Cir. 1981)

6. Mitsubishi Heavy Indus., Ltd. v. Stone \& Webster, Inc., No. 08 Civ. 00509 (JGK) Laws:

7. Kuwait procedural Law

8. Qatar Arbitration Law

9. American Federal Arbitration Act

10. Belgian Judicial Code of 1985

11. Dutch Civil Procedural Law issued July 1st, 1986

12. British Columbia International Commercial Arbitration in Canada

13. Swiss Private International Law of 1987

14. UK Arbitration Act 1996

15. US Revised Uniform Arbitration Act

16. UNCITRAL Rules

17. UCC

18. ICC Rules

19. LCIA 